\title{
PENGARUH KOMPETENSI DAN LINGKUNGAN KERJA TERHADAP KINERJA TENAGA FARMASI (STUDI KASUS RUMAH SAKIT UMUM DAERAH MAJALAYA)
}

\author{
Mieke Wijaya Putri \\ Faculty Of Management Universitas Islam Bandung \\ e-mail:miekewijaya417@yahoo.com
}

\begin{abstract}
Working performance is the result of work gained by quality and quantity, achieved by an employee in carrying out tasks in accordance with the responsibilities given to him. There are a number of things that can affect performance, which are competence and working environment. This study aims to analyze competencies, working environment, and performance of pharmaceutical workers and to analyze the influence of competencies and work environment on the performance of pharmaceutical workers at the Majalaya General Regional Hospital (RSUD Majalaya) either partially or simultaneously. As for the sample used in this research is fourty-six pharmacists in the Pharmacy Installation of the Majalaya General Regional Hospital (RSUD Majalaya). Data collection techniques were carried out through observation, questionnaires and interviews. The result of this research showed that the competency of Pharmaceutical Workers according to the evaluation of Pharmaceutical workers is in line with the head assessment which both were found that the competency variables were in sufficient category, also the working environment is in line with The head evaluation which both are in good category, while the performance results according to the Pharmacist's assessment is also in line with the assessment results of the head of Pharmacy Installation, which are, both in the excellent category. Moreover, The T test result for the competency variables and working environment variables obtained there are influential on the performance of pharmacists at the Majalaya General Regional Hospital, while the results of the $F$ test showed there is a significant relationship between competence and working environment on the performance of pharmacy staff at the Majalaya General Regional Hospital.
\end{abstract}

Keywords: Working Performance, Competency, Working Environment, Pharmaceutical Workers, Leader

\section{Pendahuluan}

\section{Latar Belakang}

Pembangunan sumber daya manusia merupakan salah satu tujuan pembangunan nasional, hal ini tertuang dalam program-program pemerintah khususnya bidang kesehatan melalui departemen kesehatan yakni sesuai dengan visinya "Indonesia Sehat 2010" yang bertujuan bahwa masyarakat Indonesia penduduknya hidup dalam lingkungan dan perilaku sehat, mampu menjangkau pelayanan kesehatan yang bermutu, adil, dan merata serta memiliki derajat kesehatan yang setinggitingginya. (Depkes, 2008).

Kinerja Sumber daya manusia di dalam sebuah rumah sakit adalah merupakan aspek penting untuk keberlangsungan suatu rumah sakit.
Tersedianya suatu kinerja sumber daya manusia yang baik seperti dokter, Farmasi, Apoteker, Analis Kesehatan, Radiologi, Kemoterapi, Bidan, Perawat, dan sebagainya sangat mempengaruhi kualitas dari rumah sakit tersebut. Sebagai mana telah diketahui bahwa suatu kinerja yang bagus tentu akan menghasilkan hasil kinerja yang bagus pula. Pada prinsipnya seorang tenaga kefarmasian harus memiliki kompetensi yang di dukung oleh lingkungan kerja yang memadai agar dapat tercipta kinerja tenaga kefarmasian yang optimal.

Adapun permasalah yang terjadi di Rumah Sakit Umum Daerah Majalaya yaitu waktu tunggu untuk mendapatkan obat-obatan di Instalasi farmasi atau apotek rumah sakit, yang mana menurut 
Kepmenkes No 129/ Menkes/ SK/ II/ 2008 tentang pelayanan resep baik obat jadi maupun obat racikan yaitu menurut Kepmenkes No

Menkes/Sk/II/2008, lama waktu tunggu obat jadi $\leq 30$ menit dan obat racikan $\leq$ 60 menit, masalah yang saya temui di rumah sakit umum daerah majalaya yaitu waktu tunggu yang melebihi standar yang ditentukan oleh Kepmenkes No 129/ Menkes/SK/II/2008, hal tersebut diduga oleh karena kurangnya kompetensi tenga farmasi yang sebabkan oleh kurangnya pelatihan yang diadakan oleh pihak rumah sakit kepada tenaga farmasi.

Dari hasil wawancara peneliti terhadap pasien di Rumah sakit Umum daerah Majalaya:

1. Pasien pertama mengatakan bahwa dampak dari lamanya waktu tunggu untuk Mendapatkan obat adalah mereka tidak bisa langsung mengkonsumsi obat tersebut secepatnya, hal tersebut diduga oleh karna costumer servicedi instalasi farmasi yang masih harus di perbaiki.

2. Pasien ke dua mengeluhkan bahwa terlalu banyak prosedur yang harus di lakukan sebelum melakukan pengambilan obat sehingga membutuhkan waktu tunggu yang lama untuk mendapatkan obat, hal tersebut di duga karna sistem pengambilan obat yang belum baik.

3. Kemudian hasil wawancara penulis terhadap pasien ketiga mengeluhkan lamanya waktu tunggu untuk pengambilan obat yang memakan waktu lebih dari satu jam, hal tersebut berdampak oleh karna kurangnya produktifitas kerja karyawan di Instalasi farmasi.

$$
\text { Adapun pelatihan yang }
$$

dilakukan oleh Rumah Sakit Umum Daerah Majalaya yaitu di ikuti oleh petugas atas nama Meta muliawati pada tanggal 3 juni 2017 yang bertempat di Lombok Nusa Tenggara Barat, dengan nama kegiatan yaitu Pelatihan Apoteker.
Berdasarkan data laporan kinerja tahunan Rumah Sakit Umum Daerah Majalaya di atas, terdapat permasalahan yang akan menentukan kompetensi yaitu pelatihan hanya dilakukan 1 kali dalam satu tahun dan pelatihan tidak diberikan kepada seluruh tenaga kefarmasian melainkan hanya kepada orang tertentu saja.

Permasalahan kedua yang juga di duga sebagai penyebab lamanya waktu tunggu di Intalasi Farmasi yaitu tentang lingkungan kerja di perkuat dengan data yang penulis dapatkan di Rumah Sakit Umum Daerah Majalaya yaitu sebagai berikut: Jumlah alat farmasi yang terdapat di ruang Instansi farmasipada tahun 2017 yaitu sebanyak 33 alat, dilihat bahwa terdapat beberapa alat yang kondisinya rusak berat yaitu sebanyak 1 alat dengan persentase (3\%) , kurang baik yaitu 8 alat dengan persentase (22\%), dan ada juga yang kondisinya masih baikyaitu sebanyak 28 alat dengan persentase $(76 \%)$, dengan jumlah alat yang rusak berat dan kurang baik, di duga dapat mempengaruhi kinerja tenaga kefarmasian dan memperpanjang waktu tunggu dalam pemberian obat.

Sedangkan data hubungan kerja dan layanan kerja yang penulis dapatkan dari Rumah Sakit Umum Daerah Majalaya yaitu salah satunya adalah jumlah tenaga kefarmasian yang bekerja dalam tiap ruangan apotek, diketahui bahwa jumlah tenaga kefarmasian yang bekerja di Rumah Sakit Umum Daerah Majalaya yaitu 46 orang yang ada di masing-masing ruangan seperti, Rawat jalan, Rawat Inap, Depo IGD, Depo TBS, gudang farmasi, dan Apoteker farmasi klinik. Namun terjadi ketidak cocokan antara jumlah tenaga kerja yang shift lebih sedikit dari yang non shift, yang mana jumlah tenaga kerja non shif seharusnya lebih sedikit dari pada yang shift karna beban kerja (workload) untuk yang shit lebih berat, sehingga menjadikan karyawan menjadi kelelahan 
hal tersebut di duga dapat mempengaruhi kinerja tenaga Farmasi yang menyebabkan waktu tunggu untuk pengambilan obat menjadi lebih lama.

Pada prinsipnya seorang tenaga kefarmasian harus kompeten dan didukung dengan lingkungan kerja yang baik agar dapat terciptanya kinerja Tenaga kefarmasian yang optimal. Namun realitanya masih terdapat kekurangan baik dari segi kompetensi maupun lingkungan kerja yang belum memadai di Rumah Sakit Umum Daerah Majalaya. Dari permasalahan tersebut maka penulis tertarik untuk melakukan penelitian dalam bentuk tesis dengan judul " Pengaruh kompetensi dan lingkungan kerja terhadap kinerja tenaga farmasi (Studi kasus pada Rumah Sakit Umum Daerah Majalaya)"

\section{Identifikasi Masalah}

Berdasarkan latar Belakang masalah di atas, maka dapat diidentifikasi masalah yaitu sebagai berikut:

1. Bagaimana kompetensi tenaga farmasi di Rumah Sakit Umum Daerah Majalaya?

2. Bagaimana lingkungan kerja tenaga farmasidi Rumah Sakit Umum Daerah Majalaya?

3. Bagaimana kinerja tenaga farmasi di Rumah Sakit Umum daerah Majalaya?

4. Bagaimana pengaruh kompetensi dan lingkungan kerja terhadap kinerja tenaga farmasi di Rumah Sakit Umum daerah Majalaya secara parsial maupun secara simultan?

\section{Tujuan Penelitian}

Berdasarkan Identifikasi masalah di atas, maka tujuan dari penelitian ini adalah:

1. Untuk menganalisis kompetensi tenaga farmasi di Rumah Sakit Umum Daerah Majalaya.
2. Untuk menganalisis Lingkungan kerja tenaga farmasi di Rumah Sakit Umum Daerah Majalaya.

3. Untuk menganalisis kinerja tenaga farmasi di Rumah Sakit Umum daerah Majalaya.

4. Untuk menganalisis pengaruh kompetensi dan lingkungan kerja terhadap kinerja tenaga farmasi di Rumah Sakit Umum Daerah Majalaya secara parsial maupun secara simultan

4. Manfaat Dan Kegunanaan Penelitian

1. Peneliti

Penelitian yang dilakukan diharapkan dapat meningkatkan kompetensi tentang manajemen sumber daya manusia, khususnya tentang pengaruh kompetensi dan lingkungan kerja terhadap kinerja tenaga farmasi di Rumah Sakit Umum Daerah Majalaya.

2. Rumah Sakit

Penelitian yang dilakukan diharapkan dapat memberikan kontribusi kepada pihak rumah sakit terhadap pengaruh kompetensi dan lingkungan kerja terhadap kinerja tenaga farmasi di Rumah Sakit Rumah Sakit Umum Daerah Majalaya

3. Peneliti berikutnya

Penelitian yang dilakukan di harapkan dapat memberikan masukan kepada peneliti lainnya terhadap terhadap pengaruh kompetensi dan lingkungan kerja terhadap kinerja tenaga farmasi di Rumah Sakit Rumah Sakit Umum Daerah Majalaya sehingga peneliti berikutnya dapat melakukan penelitian yang belum pernah dilakukan dalam penelitian ini.

\section{Kerangka Pemikiran Dan Hipotesis}

\section{Kompetensi Tenaga Farmasi} Pada suatu organisasi seperti rumah sakit, kompetensi dari para 
pegawai seperti tenaga kefarmasian sangat diperlukan untuk memberikan pelayanan yang maksimal kepada para pasien. Menurut Wibowo (2013), pengertian Kompetensi merupakan kemampuan melaksanakan pekerjaan atau tugas yang didasari ketrampilan maupun pengetahuan dan didukung oleh sikap kerja yang ditetapkan oleh pekerjaan. Kompetensi menunjukan pengetahuan, ketrampilandan sikap tertentu dari suatu profesi dalam ciri keahlian tertentu, yang menjadi ciri dari seorang profesional.

Kompetensi yang dimiliki tenaga kefarmasian sangat menentukan terhadap peningkatan kinerja tenaga kefarmasian itu sendiri, dengan kompetensi yang dimilki oleh pegawai yang sesuai dengan bidangnya maka pegawai akan memiliki kinerja yang di harapkan oleh Instansi tempat ia bekerja.

\section{Lingkungan Kerja Tenaga Farmasi}

Lingkungan kerja merupakan lingkungan dimana para karyawan dapat melaksanakan tugasnya sehari-hari dengan keseluruhan sarana dan prasarana kerja yang diperlukan untuk melaksanakan tugas-tugas tersebut (Sri Widodo 2015:95). Lingkungan kerja yang aman, nyaman dan berseih dapat membuat para karyawan merasa betah dalam menyelesaikan pekerjaaan serta mampu mencapai suatu hasil yang optimal.

Lingkungan kerja terbagi atas 2 macam yaitu Lingkungan Kerja Fisik dan lingkungan kerja psikologis (Non fisik), Menurut Sedarmayanti (2014:26) lingkungan kerja fisik adalah semua keadaan berbentuk fisik atau kondisi kerja yang terdapat di sekitar tempat kerja yang dapat mempengaruhi pegawai baik secara langsung maupun tidak langsung dan beberapa unsur lingkungan kerja fisik seperti warna, kebersihan, sirkulasi udara, sedangkan lingkungan kerja non fisik adalah semua keadaan yang terjadi yang berkaitan dengan layanan kerja, hubungan kerja, baik hubungan dengan atasan maupun hubungan sesama rekan kerja, ataupun hubungan dengan bawahan.

\section{Kinerja Tenaga Farmasi}

Kinerja adalah kesediaan seseorang atau kelompok orang untuk melakukan sesuatu kegiatan dan menyempurnakannya sesuai dengan tanggung jawabnya dengan hasil seperti yang diharapkan. Dari berbagi pengertian diatas maka dapat disimpulkan kinerja tenaga farmasi adalah hasil kerja tenaga farmasi baik secara kualitas maupun kuantitas yang dicapai oleh tenaga kefarmasian dalam melaksanakan pekerjaannya sesuai dalam uraian tugas dibandingkan dengan standar yang telah ditetapkan.

\section{Kerangka Pemikiran}

\begin{tabular}{|c|c|}
\hline $\begin{array}{l}\text { Kompetensi }\left(\mathrm{X}_{1}\right) \\
\text { 1. Motivasi }\end{array}$ & \\
\hline $\begin{array}{l}\text { 2. Sifat } \\
\text { 3. Percaya diri } \\
\text { 4. Pengetahuan } \\
\text { 5. Kemampuan } \\
\text { Srinivas R. Kandula } \\
(2013: 6)\end{array}$ & $\begin{array}{l}\text { Kinerja }(Y) \\
\text { 1. Kualitas Kerja } \\
\text { 2. Inisiatif } \\
\text { 3. Ketepatan } \\
\text { waktu/produkti } \\
\text { vitas }\end{array}$ \\
\hline $\begin{array}{l}\text { Lingkungan kerja } \\
\left(\mathrm{X}_{2}\right) \\
\text { 1. Hubungan } \\
\quad \text { kerja } \\
\text { 2. Kondisi kerja } \\
\text { 3. Layanan kerja } \\
\text { Siagian. S } \\
(2015: 134)\end{array}$ & $\begin{array}{l}\text { 4. Kemampuan } \\
\text { 5. Komunikasi } \\
\text { Gibson, } \\
\text { Ivancevich dan } \\
\text { Donnely dalam } \\
\text { Arif Ramdhani } \\
(2013: 22)\end{array}$ \\
\hline
\end{tabular}

\section{Hipotesis Penelitian}

Hipotesis Utama: Terdapat pengaruh $\begin{array}{lr}\text { positif } & \text { dan } \\ \text { signifikan } & \\ \text { kompetensi } & \text { dan } \\ \text { lingkungan } & \text { kerja }\end{array}$ 


$\begin{array}{lr}\text { terhadap } & \text { kinerja } \\ \text { tenaga } & \\ \text { kefarmasian } & \text { di } \\ \text { Rumah } & \text { Sakit } \\ \text { Umum Daerah } \\ \text { Majalaya. }\end{array}$

Sub Hipotesis $1 \quad$ : Terdapat pengaruh positif dan signifikan kompetensi terhadap kinerja tenaga kefarmasian di Rumah Sakit Umum Daerah Majalaya

Sub Hipotesis 2 : Terdapat pengaruh positif dan signifikan lingkungan Kerja terhadap kinerja tenaga kefarmasian di Rumah Sakit Umum Daerah Majalaya.

\section{Pembahasan}

\section{a. Kajian Teori}

Grand theory yang digunakan untuk penelitian ini adalah manajemen, middle theory-nya adalah Manajemen Sumber Daya Manusia (MSDM) dan applied theory-nya adalah Kompetensi, Lingkungan Kerja, dan Kinerja tenaga farmasi.

\section{b. Pengertian Manajemen}

Menurut Robbins dan Coulter (2013) adalah memantau dan mengawasi kegiatan orang lain sehingga kegiatan mereka selesai dengan efisien dan efektif. Sedangkan Menurut James. A.F. Stone (2016) manajemen adalah suatu proses perencanaan, pengorganisasian, kepemimpinan, dan pengendalian upaya dari anggota organisasi serta penggunaan sumber daya yang ada pada organisasi untuk mencapai tujuan organisasi yang telah ditetapkan sebelumnya

\section{c. Pengertian Manajemen Sumber daya manusia \\ Menurut Robert L. Mathis dan} John H. Jackson (2013) Manajemen sumber daya manusia adalah nilai kolektif dari kemampuan, pengetahuan, keterampilan, pengalaman hidup, dan motivasi tenaga kerja organisasi. Manajemen sumber daya manusia menurut Robert L. Mathis dan John H. Jackson.

\section{d. Pengertian Rumah sakit}

Menurut (WHO) Rumah sakit adalah suatu badan usaha yang menyediakan pelayanan rawat inap dan rawat jalan dan yang memberikan jasa pelayanan medis jangka pendek dan jangka panjang yang terdiri atas tindakan observasi, diagnostik, terapetik, dan rehabilitatif untuk orang orang yang menderita sakit, terluka dan untuk mereka yang melahirkan.

\section{e. Tujuan Penyelenggaraan Rumah Sakit}

Dalam pasal 3 Undang-Undang No 44 tahun 2009 tujuan penyelenggaraan Rumah Sakit adalah sebagai berikut:

1. Mempermudah akses masyarakat untuk mendapatkan pelayanan kesehatan.

2. Memberikan perlindungan terhadap keselamatan pasien, masyarakat, lingkungan rumah sakit dan sumber daya manusia di rumah sakit.

3. Meningkatkan mutu dan mempertahankan standar pelayanan rumah sakit.

4. Memberikan kepastian hukum kepada pasien, masyarakat, sumber daya manusia rumah sakit, dan Rumah Sakit.

\section{f. Peran Dan Fungsi Rumah Sakit}

Adapun peran dan fungsi rumah sakit adalah sebagai berikut: 
1. Menyediakan Pelayanan medik, Pelayanan penunjang medik, Pelayanan perawat, Pelayanan Rehabilitas, Pencegahan dan peningkatan kesehatan

2. Sebagai tempat pendidikan dan atau latihan tenaga medik atau tenaga paramedik

3. Sebagai tempat penelitian dan pengembngan lmu dan teknologi bidang kesehatan.

\section{g. Farmasi}

Farmasi adalah suatu profesi yang berkaitan dengan kesehatan yang berhubungan dengan ilmu pengetahuan kesehatan dan kimia. Farmasi adalah suatu profesi di bidang kesehatan yang meliputi kegiatan-kegiatan di bidang penemuan, pengembangan, produksi, pengolahan, peracikan, dan distribusi obat. Dalam ilmu farmasi ada empat bidang yang dipelajari, yaitu farmasi klinik, farmasi industri, farmasi sains, dan farmasi obat tradisional.

\section{Tujuan dan Fungsi farmasi dirumah sakit}

Keputusan Menteri Kesehatan Republik Indonesia Nomor 1197/MENKES SK/X/2004 Tentang Standar Pelayanan Farmasi Di Rumah Sakit adalah sebagai berikut:

a. Melangsungkan pelayanan farmasi yang optimal

b. Menyelenggarakan kegiatan pelayanan farmasi profesional berdasarkan prosedur kefarmasian dan etik profesi.

c. Melaksanakan Komunikasi, Informasi, dan Edukasi (KIE)

d. Memberikan pelayanan bermutu melalui analisa dan evaluasi untuk meningkatkan mutu pelayanan farmasi.

e. Melakukan pengawasan berdasarkan aturan-aturan yang berlaku.

f. Menyelenggarakan pendidikan dam penelitian di bidang farmasi. g. Mengadakan penelitian dan pengembangan di bidang farmasi.

h. Memfasilitasi dan mendorong tersusunnya standar pengobatan dan formulirium rumah sakit.

\section{Defenisi Kompetensi}

Konsep kompetensi telah muncul menjadi sesuatu yang penting karena kompetensi secara esensial berhubungan dengan kinerja. Kompetensi menurut UU No.13 Tahun 2003 adalah kemampuan kerja setiap individu yang mencakup aspek pengetahuan, keterampilan dan sikap kerja yang sesuai dengan standar yang ditetapkan.

\section{Kompetensi Tenaga Farmasi}

Kompetensi petugas farmasi meliputi tentang pengetahuan, keterampilan dan keahlian tenaga farmasi dalam memberikan pelayanan kefarmasian untuk pasien. Apoteker yang bekerja di rumah sakit harus memiliki pengalaman kerja minimal 2 tahun dan harus hadir setiap jam kerja.

\section{Standar Kompetensi Farmasi}

Menurut Peraturan Pemerintah Republik Indonesia Nomor 51 Tahun 2009, Ada macam-macam standar yang harus dimiliki tenaga farmasi dalam bekerja antara lain adalah:

a. Standar Profesi

b. Standar Prosedur Operasional

c. Standar Kefarmasian

\section{Cara Pengukuran Kompetensi Tenaga Farmasi}

Untuk melakukan hal ini penting bagi kita untuk membedakan aspek kinerja input, proses, output, dan penting bagi kita untuk memahami bagaimana kompetensi diukur pada masing-masing aspek kinerja tersebut.

\section{Jenis-Jenis Kompetensi}
a) Kompetensi Pedagogik
b) Kompetensi Profesional 
c) Kompetensi Sosial

\section{Manfaat kompetensi}

a) Prediktor Kesuksessan Kerja.

b) Merekrut Karyawan Yang Handal

c) Menjadi dasar dalam sistem menilai dan mengembangkan karyawan.

\section{Defenisi Lingkungan kerja}

Lingkungan kerja dalam suatu Rumah sakit perlu diperhatikan, hal ini disebabkan karena lingkungan kerja mempunyai pengaruh langsung terhadap hasil kinerja seorang karyawan atau tenaga kesehatan. Lingkungan kerja yang kondusif dapat meningkatkan kinerja karyawan dan sebaliknya, lingkungan kerja yang tidak kondusif akan dapat menurunkan kinerja karyawan.

\section{a) Lingkungan kerja tenaga farmasi \\ Menurut Undang-Undang}

Nomor 44 Tahun 2009 tentang Rumah

Sakit Rumah Sakit harus memenuhi persyaratan lokasi, bangunan, prasarana, sumber daya manusia, kefarmasian, dan peralatan. Persyaratan kefarmasian harus menjamin ketersediaan Sediaan Farmasi, Alat Kesehatan, dan Bahan Medis Habis Pakai yang bermutu, bermanfaat, aman, dan terjangkau. Selanjutnya dinyatakan bahwa pelayanan Sediaan Farmasi di Rumah Sakit harus mengikuti Standar Pelayanan Kefarmasian yang selanjutnya diamanahkan untuk diatur dengan Peraturan Menteri Kesehatan.

\section{b) Standar sarana kefarmasian di rumah sakit}

Menurut Peraturan Menteri

Kesehatan Republik Indonesia Nomor

72 Tahun 2016 Tentang Standar Pelayanan Kefarmasian Di Rumah Sakit Bab IV yang menjelaskan tentang Sumber daya kefarmasian tentang sarana adapun standar sarana kefarmasian yang harus ada dirumah sakit adalah sebagai berikut:

1. Fasilitas utama seperti Ruang Kantor/Administrasi, Ruang penyimpanan dan distribusi Sediaan farmasi, alat kesehatan, dan Bahan Medis Habis Pakai, Ruang konsultasi / konseling Obat dll.

\section{c) Standar peralatan kefarmasian di rumah sakit}

Menurut Peraturan Menteri Kesehatan Republik Indonesia Nomor 72 Tahun 2016 Tentang Standar Pelayanan Kefarmasian Di Rumah Sakit Bab IV adalah Peralatan untuk penyimpanan, peracikan dan pembuatan Obat baik steril dan nonsteril maupun aseptik/steril, Peralatan kantor untuk administrasi dan arsip, Kepustakaan yang memadai untuk melaksanakan Pelayanan Informasi Obat, Lemari penyimpanan khusus untuk narkotika, Lemari pendingin dan pendingin ruangan untuk Obat yang termolabil, Penerangan, sarana air, ventilasi dan sistem pembuangan limbah yang baik, Alarm dan lain-lain.

\section{d) Jenis lingkungan kerja}

Sedarmayanti

(2014:21)

menyatakan bahwa secara garis besar, jenis lingkungan kerja terbagi menjadi 2 yakni :

1. Lingkungan kerja fisik

Semua keadaan berbentuk fisik yang terdapat di sekitar tempat kerja yang dapat mempengaruhi karyawan baik secara langsung maupun secara tidak langsung.

2. Lingkungan Kerja Non Fisik Lingkungan kerja non fisik adalah semua keadaan yang terjadi yang berkaitan dengan hubungan kerja.

\section{Defenisi Kinerja}

Menurut Hasibuan, (2013:94) kinerja adalah suatu hasil kerja yang dicapai seseorang dalam melakukan tugas-tugas yang dibebankan kepadanya 
didasarkan atas kecakapan, pengalaman, dan kesungguhan serta waktu.

\section{a. Kinerja tenaga farmasi}

Tenaga farmasi dimintak untuk mempunyai skil dan kompetensi yang baik dalam mengemban tugasnya sebagai tenaga farmasi di rumah sakit, Apoteker di mintak untuk dapat memberikan pelayanan yang semaksimal mungkin dan bekerja sesuai dengan standar operasional prosedur sehingga tercapainya hak pasien untuk mendapatkan pelayanan yang maksimal, dan di samping itu pekerjaan yang benar dilakukan tentu memberikan rasa percaya diri akan tanggung jawab terhadap suatu tugas dan menghindari dari tuntutan hukum yang berlaku.

\section{b. Standar Kinerja Tenaga Farmasi}

Standar kinerja merupakan tingkat kinerja yang diharapkan dalam suatu organisasi, dan merupakan pembanding (benchmark) atau tujuan atau target tergantung pada pendekatan yang diambil. Standar kerja yang baik harus realistis, dapat diukur dan mudah dipahami dengan jelas sehingga bermanfaat baik bagi organisasi maupun para karyawan (Abdullah, 2014:114)

Di dalam Peraturan Pemerintah Nomor 51 Tahun 2009 tentang Pekerjaan Kefarmasian dibahas bahwa dalam menjalankan praktik kefarmasian pada Fasilitas Pelayanan Kefarmasian, Apoteker harus menerapkan Standar Pelayanan Kefarmasian yang diamanahkan untuk diatur dengan Peraturan Menteri Kesehatan.

\section{c. Fungsi Standar Kinerja}

Standar kinerja sebagaimana yang dijelaskan Abdullah (2014:115) memiliki fungsi antara lain:

1. Sebagai tolok ukur untuk menentukan keberhasilan dan ketidak berhasilan kinerja ternilai

2. Memotivasi karyawan agar bekerja lebih keras untuk mencapai standar.
3. Memberikan arah pelaksanaan pekerjaan yang harus dicapai, baik kuantitas maupun kualitas.

4. Memberikan pedoman kepada karyawan berkenaan dengan proses pelaksanaan pekerjaan guna mencapai standar kinerja yang ditetapkan

\section{d. Penilaian Kinerja}

Menurut Simamora (2014:458) penilaian kinerja adalah suatu proses dengannya suatu organisasi mengevaluasi pelaksanaan kerja individu. Kegiatan ini dapat memperbaiki keputusan-keputusan personalia dan dapat memberikan umpan balik kepada para karyawan tentang pelaksanaan kerja mereka serta memungkinkan perusahaan untuk mengetahui seberapa baik seseorang karyawan bekerja jika dibandingkan dengan standar - standar organisasi.

\section{e. Tujuan dan Manfaat Penilaian Kinerja \\ Menurut (Belarmino: 2013, 62-} 63) Tujuan dan Manfaat Penilaian Kinerja adalah: Untuk menilai kinerja setiap individu dalam organisasi dalam menentukan jumlah dan jenis kompensasi yang merupakan hak bagi setiap individu dalam organisasi, pengembangan dari diri setiap individu dalam organisasi Penilaian kinerja pada tujuan ini bermanfaat untuk pengembangan karyawan yang memiliki kinerja rendah yang membutuhkan pengembangan baik melalui pendidikan formal maupun pelatihan, pemeliharaan berbagai sistem yang ada dalam organisasi memiliki sub sistem yang saling berkaitan antara satu sub sistem dengan sub sistem lainnya, oleh karena itu perlu dipelihara dengan baik, Penilaian kinerja akan memberi manfaat sebagai dasar tindak lanjut dalam posisi pekerjaan karyawan di masa akan datang. Hal ini berkaitan dengan pengambilan keputusan. 


\section{f. Akreditasi Rumah Sakit}

Hasil Akreditasi Rumah Sakit tidak terlepas dari hasil Kinerja dan mutu dari Rumah sakit tersebut yang mana menurut Peraturan Menteri Kesehatan Republik Indonesia Nomor 34 tahun 2017 Tentang Akreditasi Rumah Sakit BAB I Pasal 1 menyatakan bahwa:

1. Akreditasi Rumah Sakit adalah pengakuan terhadap mutu pelayanan Rumah Sakit, setelah dilakukan penilaian bahwa Rumah Sakit telah memenuhi Standar Akreditasi.

2. Standar Akreditasi adalah pedoman yang berisi tingkat pencapaian yang harus dipenuhi oleh rumah sakit dalam meningkatkan mutu pelayanan dan keselamatan

\section{Metode Penelitian}

\section{Jenis penelitian}

Penelitian ini menggunakan metode penelitian kuantitatif dengan pendekatan desktiptif dan verifikatif

\section{Populasi Dan Sampel Penelitian}

\begin{tabular}{|l|c|c|c|}
\hline $\begin{array}{l}\text { DIMENSI } \\
\text { JABATAN }\end{array}$ & PNS & $\begin{array}{c}\text { HONOR } \\
\text { ER }\end{array}$ & JUMLAH \\
\hline Apoteker & 2 & 13 & 15 \\
\hline $\begin{array}{l}\text { Asisten } \\
\text { Apoteker }\end{array}$ & 6 & 25 & 31 \\
\hline Total & 8 & 38 & 46 \\
\hline
\end{tabular}

Dari tabel di atas menunjukkan populasi berjumlah 46 orang yang terdiri dari apoteker yaitu sebanyak 15 orang, asisten Apoteker sebanyak 31 orang, dengan total semua populasi yaitu 46 orang tenaga farmasi. Sampel yang digunakan dalam penelitian ini adalah total populasi dari semua tenaga farmasi yang ada di Rumah Sakit Umum Daerah Majalah.

\section{Operasional Variabel}

a. Variabel Independen (X)

1. Kompetensi

Kompetensi merupakan kemampuan melaksanakan pekerjaan atau tugas yang didasari ketrampilan maupun pengetahuan dan didukung oleh sikap kerja yang ditetapkan oleh pekerjaan. Indikator:

a. Motif (Motivasi

b. Trait (Tingkat rasa empati)

c. Self concept (Tingkat rasa percaya diri)

d. Knowledge (Pengetahuan)

e. Skill ( Keterampilan)

\section{Lingkungan Kerja}

Lingkungan kerja merupakan lingkungan dimana para karyawan dapat melaksanakan tugasnya sehari-hari dengan keseluruhan sarana dan prasarana kerja yang diperlukan untuk melaksanakan tugas-tugas tersebut.

Indikator:

a. Hubungan kerja

b. Kondisi kerja

c. Layanan Kerja

\section{b. Variabel Dependen (Y)}

Kinerja merupakan suatu istilah secara umum yang digunakan sebagian atau seluruhtindakan atau aktivitas dari suatu organisasi pada suatu periode dengan suatu referensi pada sejumlah standar seperti biaya masa lalu yang diproyeksikan dengan dasar efisiensi, pertanggungjawaban/ akuntabilitas manajemen dan semacamnya.

Indikator:
a. Kualitas kerja
b. Inisiatif
c. Ketepatan waktu
d. Kemampuan
e. Komunikasi

\section{Teknik Pengumpulan Data}
a. Observasi
b. Kuisioner
c. Wawancara

6. Rancangan Analisis Data a. Pengujian Validitas

Uji validitas digunakan untuk mengukur sah atau valid tidaknya suatu kuesioner. Suatu kuesioner dikatakan valid jika pertanyaan pada kuesioner mampu untuk mengungkapkan sesuatu 
yang akan diukur oleh kuesioner tersebut.

\section{b. Pengujian Reliabilitas}

Pengujian reliabilitas adalah alat untuk mengukur suatu kuesioner yang merupakan indikator dari variabel atau konstruk. Suatu kuesioner dikatakan reliabel atau handal jika jawaban seseorang terhadap pertanyaan adalah konsisten atau stabil dari waktu ke waktu.

\section{Analisis Data}

\section{a. Analisis Deskriptif}

Analisis deskriptif bertujuan untuk melakukan deskriptif mengenai kompetensi dan lingkungan kerja terhadap kinerja sebagai kuantitatif sub variabel.

\section{b. Analisis Verifikatif}

Analisis Verifikatif adalah perhitungan statistik yang digunakan untuk menguji variabel X1 (Kompetensi) dan variabel X2 (Lingkungan Kerja) terhadap variabel $\mathrm{Y}$ (Kinerja) yang diteliti. Verifikatif berarti menguji teori dengan pengujian suatu hipotesis apakah diterima atau ditolak.

8. Uji Asumsi Klasik a. Uji Normalitas

Uji normalitas bertujuan untuk mengetahui suatu distribusi sebuah data mengikuti atau mendekati distribusi normal, yaitu distribusi data dengan bentuk loncengan dan distribusi data tersebut tidak melengceng ke kiri atau melengceng ke kanan.

\section{b. Uji Multikolinieritas}

Uji multikolonieritas bertujuan untuk menguji apakah model regresi ditemukan adanya korelasi antar variabel bebas (independen).

\section{c. Uji Heteroskedastisitas}

Uji Heteroskedastisitas bertujuan untuk menguji apakah dalam model regresi terjadi ketidaksamaan Variance dari residual satu pengamatan ke pengamatan lain.

\section{Uji Hipotesis}

Untuk menguji hipotesis dalam penelitian ini dilakukan dengan menggunakan uji t dan uji $\mathrm{F}$.

\section{Pembahasan Hasil Penelitian}

a. Uji Validitas

Suatu instrumen dapat dinyatakan valid apabila instrumen tersebut mampu mengukur apa yang diinginkan dan dapat mengungkapkan data dari variabel yang diteliti secara tepat, dalam penelitian ini nilai rtabel yaitu 0.291, untuk item pertanyaan mengenai kompetensi ada 15 pertanyaan yang mana semua pertanyaan tersebut hasilnya Valid, untuk lingkungan kerja item pertanyaan yang digunakan juga sebanyak 15 pertanyaan yang mana semua pertanyaannya Valid, sedangkan untuk item pertanyaan mengenai Kinerja item pertanyaan yang digunakan adalah sebanyak 12 pertanyaan yang mana semua pertanyaannya Valid.

\section{b. Uji Reliabilitas}

\begin{tabular}{|c|c|c|}
\hline Variabel & $\begin{array}{c}\text { Nilai } \\
\text { Reliabilitas }\end{array}$ & Ket \\
\hline Kompetensi & 0.856 & Reliabel \\
\hline $\begin{array}{c}\text { Lingkungan } \\
\text { Kerja }\end{array}$ & 0.757 & Reliabel \\
\hline Kinerja & 0.711 & Reliabel \\
\hline
\end{tabular}

\section{c. Uji Simultan}

Berdasarkan uji Anova diperoleh nilai $F_{\text {hitung }}=12.502$ dan nilai Sig. 0.000. Dengan mengambil nilai $\alpha=$ 0.05 atau $5 \%$, maka dapat disimpulkan $\mathrm{H}_{0}$ di tolak dan $\mathrm{H}_{1}$ diterima karena nilai Sig. $=0.000<$ alpha $=0.05$. Sehingga dapat disimpulkan pengujian signifikan yang artinya variabel kompetensi $\left(\mathrm{X}_{1}\right)$, dan lingkungan kerja $\left(\mathrm{X}_{2}\right)$, secara bersama-sama berpengaruh signifikan terhadap kinerja tenaga farmasi (Y) di Rumah Sakit Umum Daerah Majalaya. 


\section{d. Uji Parsial}

1. Hasil Uji t hitung untuk variabel Komptensi $\left(\mathrm{X}_{1}\right)$, diperoleh nilai uji t hitung $=4.687$ dengan $\mathrm{Sig}$ (tingkat signifikansi) $=0,000$, dengan nilai $\alpha=5 \%$ atau 0.05 . Berdasarkan kriteria uji maka variabel kompetensi secara parsial berpengaruh terhadap kinerja tenaga farmasi (Y) di Rumah Sakit Umum Daerah Majalaya.

2. Hasil Uji t hitung untuk variabel Lingkungan Kerja $\left(\mathrm{X}_{2}\right)$, diperoleh nilai uji $\mathrm{t}=2.247$ dan $\mathrm{Sig}$ (tingkat signifikansi) = 0,030 , dengan nilai $\alpha=5 \%$ atau 0.05 . Berdasarkan kriteria uji maka variabel Lingkungan Kerja secara parsial berpengaruh terhadap kinerja tenaga farmasi (Y) di Rumah Sakit Umum Daerah Majalaya.

3. Dari penjelasan diatas dapat disimpulkan bahwa variabel kompetensi dan lingkungan kerja semuanya berpengaruh secara parsial terhadap kinerja tenaga farmasi (Y) di Rumah Sakit Umum Daerah Majalaya.

Berdasarkan hasil di atas, dari kedua variabel bebas yang paling berpengaruh terhadap variabel kinerja tenaga farmasi adalah variabel yangmempunyai nilai $t$ hitung yang besar. Dari hasiltersebut variabel yang paling berpengaruh adalah kompetensi.

Berdasarkan hasil perhitungan dipeoleh nilai $\mathbf{R}^{2}$ terkoreksi $=0,338$

$$
\begin{aligned}
\mathrm{KD} & =\mathrm{R}^{2} \times 100 \% \\
& =0,338 \times 100 \% \\
& =33.8 \%
\end{aligned}
$$

Dengan demikian kontribusi variabel kompetensi dan lingkungan kerja tenaga farmasi di Rumah Sakit Umum Daerah Majalaya sebesar 33.8\%, sisanya sebesar $66.2 \%$ variabel kinerja tenaga farmasi diberikan oleh faktor lain yang tidak teridentifikasi (dianalisis)

\section{Penutup}

a. Kesimpulan

1. Kompetensi Tenaga Farmasi di Rumah Sakit Umum Daerah Majalaya berdasarkan penilaian tenaga farmasi yaitu masuk kedalam kategori cukup, yang aritnya kompetensi tenaga farmasi yang telah diukur sesuai dengan dimensi Motif, Trait, Self Concept, Knowledge, dan Skill, Hal tersebut juga sejalan dengan Penilaian Pimpinan yang mana kompetensi tenaga farmasi juga masuk kedalam kategori cukup. Namun dalam hal ini, dimensi yang masih dirasa kurang untuk variabel kompetensi Menurut Penilaian tenaga farmasi adalah dimensi Knowledge, sedangkan dimensi yang masih dirasa kurang untuk variabel kompetensi Menurut Penilaian Pimpinan adalah dimensi Skill. Sejalan juga dengan Laporan Hasil Pelaksanaan Survey Kepuasan Pasien di Instalasi Farmasi RSUD Majalaya tahun 201880.919 $\%$ (Baik). Adapun dari 9 unsur pelayanan, unsure yang harus mendapat perhatian adalah unsur Waktu Pelayanan (2.980), Maklumat Pelayanan (3.060) dan Produk Layanan (3.160).

2. Lingkungan Kerja Tenaga Farmasi di Rumah Sakit Umum Daerah Majalaya berdasarkan penilaian tenaga farmasi yaitu masuk kedalam kategori baik, yang artinya Lingkungan Kerja tenaga farmasi yang telah di ukur berdasarkan dimensi Hubungan Kerja, Kondisi Kerja, Layanan Kerja. Hal tersebut juga sejalan dengan Penilaian Pimpinan yang mana Lingkungan Kerja tenaga farmasi juga masuk kedalam kategori baik. Namun dalam hal ini, dimensi yang masih dirasa kurang untuk variabel Lingkungan Kerja Menurut Penilaian tenaga 
farmasi adalah dimensi Layanan Kerja, sedangkan dimensi yang masih dirasa kurang untuk variabel Lingkungan Kerja Menurut Penilaian Pimpinan juga sama yaitu dimensi Layanan Kerja, Sejalan juga dengan Laporan Hasil Pelaksanaan Survey Kepuasan Pasien di Instalasi Farmasi RSUD Majalaya tahun 201880.919 $\%$ (Baik). Adapun dari 9 unsur pelayanan, unsure yang harus mendapat perhatian adalah unsur Waktu Pelayanan (2.980), Maklumat Pelayanan (3.060) dan Produk Layanan (3.160).

3. Kinerja Tenaga Farmasi di Rumah Sakit Umum Daerah Majalaya berdasarkan penilaian tenaga farmasi yaitu masuk kedalam kategori tinggi, yang artinya variabel Kinerja tenaga farmasi yang telah di ukur berdasarkan dimensi Kualitas Kerja, Inisiatif, Ketepatan Waktu, Kemampuan, Komunikasi. Hal tersebut juga sejalan dengan Penilaian Pimpinan yang mana Kinerja tenaga farmasi juga masuk kedalam kategori tinggi. Namun dalam hal ini, dimensi yang masih dirasa kurang untuk variabel Kinerja Menurut Penilaian tenaga farmasi adalah dimensi Komunikasi, sedangkan dimensi yang masih dirasa kurang untuk variabel Kinerja Menurut Penilaian Pimpinan juga sama yaitu dimensi Komunikasi, Sejalan juga dengan Laporan Hasil Pelaksanaan Survey Kepuasan Pasien di Instalasi Farmasi RSUD Majalaya tahun $201880.919 \%$ (Baik). Adapun dari 9 unsur pelayanan, unsure yang harus mendapat perhatian adalah unsur Waktu Pelayanan (2.980), Maklumat Pelayanan (3.060) dan Produk Layanan (3.160).

4. kinerja tenaga farmasi di Rumah Sakit Umum Daerah Majalaya baik secara parsial maupun simultan, dimana semakin tinggi kompetensi dan semakin baiknya lingkungan kerja maka akan meningkatkan kinerja tenaga farmasi di Rumah Sakit Umum Daerah Majalaya.

\section{b. Saran}

a. Rumah Sakit

Saran Peneliti bagi Rumah Sakit Umum Daerah Majalaya yaitu agar dapat menerapkan pelatihanpelatihan kepada semua tenaga kesehatan baik yang bukan tenaga kesehatan agar kedepannya Rumah Sakit Umum Daerah mempunyai karyawan yang memiliki ketrampilan, kompetensi dan daya saing yang kuat dengan rumah sakit lain yang ada disekitar Majalaya.

b. Tenaga Farmasi

Saran Peneliti Untuk Tenaga Farmasi agar lebih meningkatkan lagi kompetensinya yang mana menurut hasil penelitian peneliti didapatkan kompetensi Tenaga farmasi berada dalam kategori cukup, dan kedepannya bisa berada dalam kategori sangat tinggi, dengan cara menampah ilmu pengetahuan seperti kuliah, seminar, studi banding dan lain sebagainya.

c. Penelitian berikutnya

Dari hasil penelitian ini didapatkan $33.8 \%$ pengaruh kompetensi dan lingkungan kerja terhadap kinerja dan selebihnya yaitu $66.2 \%$ diberikan oleh faktor lain yang tidak teridentifikasi, saran untuk peneliti selanjutnya yaitu untuk dapat mengangkat variabel lain yang berpengaruh terhadap kinerja tenaga farmasi.

\section{DAFTAR PUSTAKA}

Abdullah, Ma'ruf. 2014. Manajemen dan Evaluasi Kinerja Karyawan. Yogyakarta: Aswaja Pressindo.

Albert wibi rahman. 2015. Pengaruh Kompetensi Dan Lingkungan Kerja 
Terhadap Kinerja Perawat Bagian Rawat Inap Pada Rumah Sakit Umum Daerah (RSUD) Petala Bumi Pekanbaru. Jom Fekon Vol.2 no.1

Alex S. Nitisemito, 2014, Manajemen Personalia, Ghalia Indonesia, Jakarta.

Arep, Ishak dan Hendri Tanjung. Manajemen Motivasi. Jakarta: Grasindo. 2013

Belarmino, M. M and Mii. M. 2013. Agrobacterium-mediated genetic transformation of a Phalaenopsis orchid. Plant cell report 19 : 435-442.

Coulter, Robbins. 2013. Manajemen, Edisi Ketujuh, Edisi Indonesia, Jilid Kesatu.

Jakarta : PT. Indeks Group Gramedia.

Daft, Richard L dan Dorothy Marcic. 2013. Management: The New Workplace 7th edition. China: Cengage Learning.

Depkes RI, 2009, Peraturan Pemerintah No. 51 Tahun 2009 Tentang Pekerjaan Kefarmasian, Departemen Kesehatan RI: Jakarta.

Departemen Kesehatan RI. 2008. Profil kesehatan Indonesia 2007.Jakarta : Depkes RIJakarta .

Departemen Kesehatan RI, 2004, Keputusan Menteri Kesehatan Republik Indonesia Nomor 1197/Menkes/SK/X/2004, tentang Standar Pelayanan Farmasi di Rumah Sakit, Jakarta.
Dessler, Gary. 2015. Manajemen

Sumber Daya Manusia. Jakarta:

Salemba

Empat

Ghozali, Imam. (2016). Aplikasi Analisis Multivariate dengan Program IBM SPSS 23. Semarang: BPFE Universitas Diponegoro

Gibson, James L., Donnelly Jr, James H., Ivancevich, John M., Konopaske, Robert (2013). Organizationa Behavior, Structure, Processes, Fourteenth Edition (International Edition).1221 Avenue of The Americas, New York, NY 10020: McGraw-Hill.

Keputusan Menteri Kesehatan Republik Indonesia Nomor 129/Menkes/ SK/III/2008; 2008

Keputusan Majelis Asosiasi Pendidikan Tinggi Farmasi Tahun 2016 tentang Standar Kompetensi Apoteker Indonesia

Lupiyoadi, Rambat. 2014. Manajemen Pemasaran Jasa. Edisi 3. Jakarta: Salemba Empat.

Mathis, Robert L dan John H. Jackson, 2013. Manajemen Sumber Daya Manusia.

Buku 1, Alih Bahasa: Jimmy Sadeli dan Bayu. Prawira Hie, Salemba Empat. Jakarta.

Menteri Kesehatan Republik Indonesia, 2010, Peraturan Menteri Kesehatan Nomor: 340/Menkes/PER/III/2010 tentang Klasifikasi Rumah 
Sakit. Jakarta: Departemen Kesehatan

Menteri Kesehatan Republik Indonesia, 2004, Keputusan Menteri Kesehatan Nomor : 1204/MENKES/SK/X/2004 tentang Persyaratan Kesehatan Lingkungan Rumah Sakit,Jakarta: Departemen Kesehatan

Peraturan Meteri Kesehatan Republik Indonesia Nomor 72 Tahun 2016 tentang Standar Pelayanan Kefarmasian di Rumah Sakit, Jakarta.

Peraturan Menteri Kesehatan Republik Indonesia Nomor 56 Tahun 2014 Tentang Klasifikasi Dan Perizinan Rumah Sakit.

Profil Rumah Sakit Umum Daera Majalaya (4 Agustus2018) diperoleh dari http://www.bandungkab.go.i d/arsip/profil-rsud-majalaya

Rivai, Veithzal dan Sagala Jauvani Ella, 2013. Manajemen Sumber Daya Manusia Untuk Perusahaan Dari Teori ke Parktik, PT. Rajawali Pers, Jakarta.

Sedarmayanti. (2014). Manajemen Sumber Daya Manusia, Reformasi Birokrasi, dan Manajemen Negeri Sipil. Bandung: Refika Aditama

Simamora, Henry. (2014). Manajemen Sumber Daya Manusia. Yogyakarta: Bagian Penerbitan Sekolah Tinggi Ilmu Ekonomi YKPN
Soedarso, Sri Widodo. 2015. Sistem Informasi Manajemen. Bandung: Manggu Media.

Sondang P Siagian, 2015, Manajemen Sumber Daya Manusia, Bumi Aksara, Jakarta.

S.P,Hasibuan, Malayu. 2013. Manajemen Sumber Daya Manusia. Jakarta: PT

\section{Bumi Aksara}

Srinivas and Padma. 2013. Impact of Services Quality on Customer Decisionin Hotel Industry. Volume 18, Issue 5.

Stoner, James.A.F. 2016. Management, Prentice Hall International,Inc Englewood Cliffs, New York

Sugiyono. (2014) Metode Penelitian Kuantitatif Kualitatif dan R\&D. Bandung : Alfabeta

Undang-Undang Nomor 13 Tahun 2003 Tentang Ketenagakerjaan

Undang-Undang RI Nomor 44 Tahun 2009 tentang Rumah Sakit

Wibowo. 2013. Manajemen Kinerja. Jakarta: Rajawali Pers 